\title{
Cerebral Cysticercosis Mimicking Malignant Glioma
}

\author{
Marcelo Jose da Silva de Magalhaes* \\ Department of Neurosurgery, Aroldo Tourinho Hospital, Brazil
}

Submission: October 15, 2016; Published: November 04, 2016

*Corresponding author: Marcelo Jose da Silva de Magalhaes, Department of Neurosurgery, Faculdades Unidas do Norte de Minas Medical School, Aroldo Tourinho Hospital, Brazil, Email: marcelo7779@yahoo.com.br

Keywords: Glioma; Neurocysticercosis; Differential diagnosis

\section{Introduction}

Cysticercosis is the most common parasitic disease worldwide; with an estimated prevalence greater than 50 million persons are infected. The life cycle of the pork tapeworm, Taenia solium, begins at the larval stage in pigs. Human tapeworm infection occurs when T. solium cysts are ingested from undercooked pork. The larvae attach to the human gut and grow into adult tapeworms. The adult tapeworm then sheds proglottids into human feces that can contaminate the pig food supply. Eggs ingested by pigs develop into the larval stage, travel through the intestinal wall, enter the bloodstream, lodge in various pig tissues, and develop into cysts. When humans ingest eggs, through fecal-oral transmission, they become dead-end hosts of the larval stage of the parasite and develop cysticercosis similar to pigs. This parasite is a leading cause of seizures and epilepsy in the developing world that is caused by infection with Taenia solium. CASE: 55-year-old man presented with a 14-day history of left lower limb numbness, unsteadiness of gait. On neurological examination, he had left lower weakness (strength, 4/5), with normal tone and deep-tendon reflexes. The plantar reflexes were normal bilaterally. Brain CT documented the presence of cystic lesions in the right frontal lobe associated with cerebral. The radiological data revealed a solitary lesion highly suggestive of high-grade glioma (Figure 1). He received a diagnosis of glioma and treated with surgical treatment. During surgical procedure were found multiples cysts containing yellowish material compatible with neurocysticercosis (Figure 2). The anatomopathological study confirmed the diagnosis of neurocysticercosis [1].

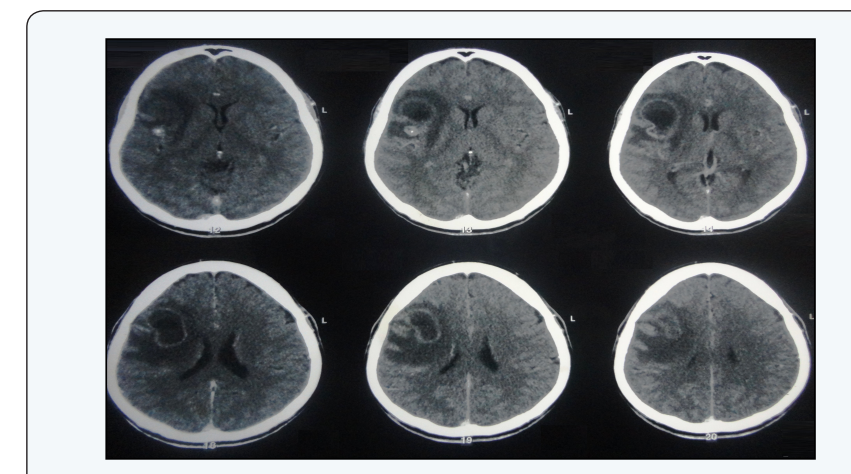

Figure 1: CT imagesdemonstratedcysticercus lesion on right hemisphere with perilesional brain edema.

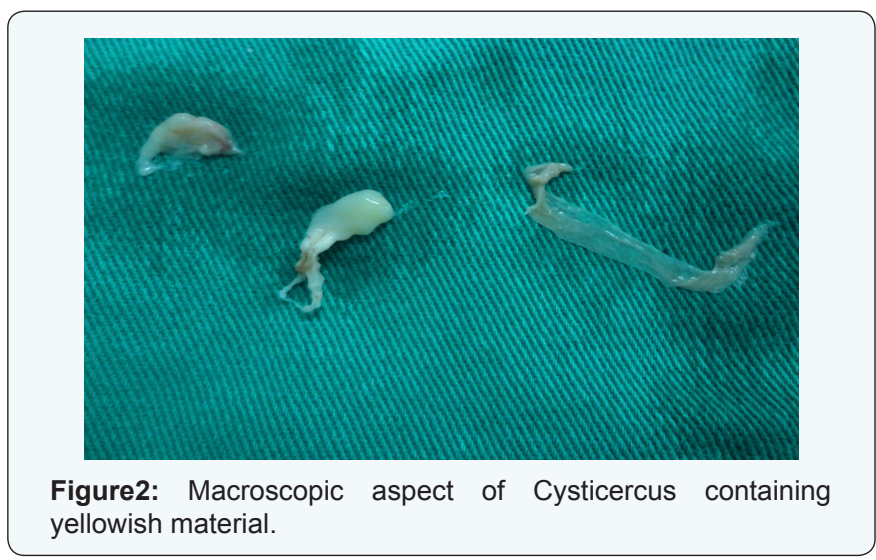

\section{References}

1. Silver SA, Erozan YS, Hruban RH (1996) Cerebral cysticercosis mimicking malignant glioma: a case report. Acta Cytol 40(2): 351-357. 
Your next submission with JuniperPublishers will reach you the below assets

- Quality Editorial service

- Swift Peer Review

- Reprints availability

- E-prints Service

- Manuscript Podcast for convenient understanding

- Global attainment for your research

- Manuscript accessibility in different formats ( Pdf, E-pub, Full Text, Audio)

- Unceasing customer service

Track the below URL for one-step submission http://juniperpublishers.com/online-submission.php 